\title{
O MOVIMENTO ANARQUISTA NO BRASIL
}

\author{
SILZA MARIA PAZELLO VALENTE ${ }^{1}$
}

VALENTE, S.M.P. O movimento anarquista no Brasil. Semina: Ci. Soc./Hum., Londrina, v. 15, n. 3, p. 260-269, set. 1994.

RESUMO: O processo histórico anarquista no Brasil possui, sob nosso ponto de vista, 3 fases pontuadas por significativos acontecimentos polfticos e económicos, que compuseram o cenário para os movimentos reivindicatórios dos trabalhadores, influenciados pelo ideário anarquista.

PALAVRAS-CHAVE: Anarquismo, Trabalhadores, Educação polttica, Brasil, Primeira República

"Quem se defende porque the tiram o ar Ao the apertar a garganta, para este há um parágrafo Que diz: ele agiu em legftima defesa. Mas O mesmo parágrafo silencia Quando vocês se defendem porque thes tiram o pão. E no entanto morrem quem não come, e quem não come o suficiente

Morre lentamente. Durante os anos todos em que morre Não the é permitido se defender."

(Brecht)

\section{1 - INTRODUÇÃo}

Tendo como tema central das reflexões o Anarquismo no Brasil, existe uma extensa bibliografia que explora minuciosamente, com profundidade e sob os mais diversos ângulos, este tema.

Bibliografia esta que, de um modo geral, correla ciona a penetração das idéias anarquistas com a imigração estrangeira - principalmente portugueses, italianos e espanhớis - e com o início do processo de industrialização no Brasil. DULLES (1977, p. 19) afirma que, em 1990, cerca de $90 \%$ da força industrial de São Paulo era composta por imigrantes e que as idéias ventiladas por eles eram idéias que

"Convenceram os governos do Sul da Europa a encorajar o êxodo dos elementos radicais dos seus paises - especialmente depois que alguns anarquistas europeus

(...) participaram de insurreições e atentados terroristas."
COSTA (1988, p. 117) diz textualmente: "A América Latina conheceria os ideais anárquicos no fim do século passado, por idéia e obra dos imigran. tes italianos europeus."

RAGO (1985) utiliza uma imagem poética comparando a vinda dos imigrantes com a invasão da Europa por Átila: para a sociedade da época, os imigrantes eram como bárbaros que levavam tudo de roldão: crenças, valores, passaram a ser questionados. Era toda uma estrutura social que, de repente, se via sacudida pelo elemento estranho com suas ralzes plantadas em outras plagas.

MAGNANI (1982), por seu lado, em monografia onde, entre outros elementos, procura levantar as tendên cias presentes na literatura, ao interpretar o movimento operário enquanto influenciado pelas idéias anarquistas, afirma que durante a 1 a República, a grande imprensa e a intelectualidade burguesa difundiam a imagem do Anar. quismo como uma planta exótica, transplantada de paj́ses onde o processo industrial estava mais avançado.

Essa cultura importada pela imigração não teria aqui condições para se aclimatar. Em primeiro lugar, pela indole do povo: pacifica, cordial, apegada à ordem; em segundo lugar, pela deseducação das massas trabalha doras que não tinham condiçōes de apreender uma doutrina, nem de desenvolver-se politicamente, sem a tutela das elites intelectuais; em terceiro lugar, porque o Brasil oferecia boas condiçöes aos trabalhadores, podendo esses ascender econômica e socialmente; e em quarto lugar, porque inexistiam, no Brasil, conflitos de classe.

A penetração das idéias anarquistas no Brasil era relacionada, por esses intelectuais, à ignorância dos trabalhadores que não se apercebiam das imensas oportunidades de ascensão que lhes eram ofertadas. Para eles, não foram, portanto, o número elevado de horas de tra.

1 - Departamento de Educaçāo/CECA - Universidade Estadual de Londrina, Caixa Postal 6001, Londrina, Paraná, Brasil, CEP $86051-970$. 
balho, a exploração do trabalho infantil, as condições insalubres das fábricas, que motivaram o operariado a se mobilizar em movimentos reivindicatórios e políticos.

A história oficial foi influenciada por essa teoria da planta exótica (FAUSTO, 1976), tanto que, segundo MAGNANI (1982), os estudos da legislação trabalhista se atêm ao perlodo após 1930, como se as lutas anteriores não tivessem ocorrido.

Os primeiros estudos sobre o Movimento Operário no Brasil, partiram de autores ligados à política operária, fosse através dos sindicatos ou dos partidos políticos e datam da década de 50 e início dos anos 60 .

Embora tivessem o mérito de descortinar o véu, deram ao anarquismo uma importância secundária, de preparo para a fundação do Partido Comunista, visto como fruto do amadurecimento da consciência de classe.

Ainda segundo MAGNANI (1982), datam do inicio da década de 60, as obras que retratam as memórias de militantes operários. Esses autores procuram contrapor suas interpretações àquelas comunistas e enxergam nas primeiras lutas trabalhistas a influência marcante do anarquismo. Evidenciam que, após 1922, o Movimento Operário se rendeu às influências do comunismo e do trabalhismo oficial e perdeu o intuito inicial tornando-se mais reformista que revolucionário.

A autora situa nesta linha Edgar Leuenroth e Edgar Rodrigues. Acrescentarlamos a estes autores EVERARDO DIAS (1977), que, embora adepto do comunismo, em suas memórias evidencia a marcante atuação anarquista na configuração do Movimento Operário do início do sé. culo.

Continuando sua análise historiográfica, MAGNANI (1982), afirma que as produçôes acadêmicas sobre o Movimento Operário datam de meados da década de 60 , mas se prendem ao Sindicalismo e partem de 1930, enfocando este ano como um marco divisório, e analisando, principalmente, o papel do Estado.

Os trabalhos mais recentes buscam fazer uma reavaliação do perlodo conhecido como $1^{\mathrm{a}}$ República e do Movimento Anarquista, procurando integrá-lo num todo maior, explicativo da conduta do operariado e analisando criticamente a estrutura sócio-econômico-politica que ensejou o desenvolvimento das idéias anarquistas nos primeiros anos do século.

Magnani situa-se nesta última linha, assim como a maioria dos autores por nós consultados e que serão referenciados no decorrer do trabalho. A autora chama ainda a atenção para o fato de que não se deve simplificar a análise da penetração do anarquismo no Brasil, julgando-o como um simples transplante de idéias que não tinham como florescer.

Concordamos plenamente com esta posição de Magnani, porque consideramos, sob a mesma ótica de MELLO (1988), que são as condiçōes particulares de cada pais que imprimem as caracteristicas de um dado momento histórico. Recusamo-nos a considerar as influências externas de maneira deterministica, privilegiando, assim, o espaço nacional como gerador de elementos impulsionadores do desenvolvimento.

Semina Ci. Soc./Hum., v. 15, n. 3, p. 260-269
A riqueza da bibliografia existente sobre o Anarquismo no Brasil, que centra sua análise nas cidades do Rio de Janeiro e São Paulo, pela importância que tiveram na implantaçäo do capitalismo industrial, induz a um viés interpretativo que leva a minimizar as experiências anarquistas ocorridas em outras cidades brasileiras, caso de Curitiba, por exemplo, que foi palco, durante as primeiras décadas deste século, de movimentos trabalhistas influenciados pelo anarquismo.

Embora tenhamos elaborado um tese de mestrado que evoca a presença anarquista em Curitiba (VALENTE, 1992), neste trabalho pretendemos recuperar apenas os traços mais gerais da penetração do ideário anarquista no Brasil, procurando dividi-lo em fases que permitam uma compreensão mais clara das ações anarquistas mais significativas em cada momento histórico.

\section{2 - FASES DO PROCESSO HISTÓRICO ANAROUISTA NO BRASIL}

O Anarquismo se fez presente no Brasil muito antes da política de imigração massiva e do processo de industrialização, embora esses dois fenômenos tenham dado o suporte necessário para a ampliação da influênca desse ideário, principalmente entre o operariado.

Inúmeras experiências de criação de núcleos habitacionais fundamentados no anarquismo, e calcados numa economia agrária e artesanal foram colocados em prática, ainda durante o periodo imperial, como atesta RODRIGUES (1969, p. 30):

"Experiências em moldes cooperativos, comunidades igualitárias de vida em comum, apareciam constantemente no Brasil, e podemos afirmar que têm sempre algo que as identifique com as idéias de Robert Owen ou Fourier."

Entre as colônias fundadas sob a inspiração anarquista, o autor cita: Guararema, no Estado de São Paulo, fundada por Artur Campagnolli, em 1888; e Cecllia, no Estado do Paraná, fundada por Giovanni Rossi, em 1890. Refere-se também à influência dos anarquistas no meio rural, organizando reuniões e palestras, com a finalidade de difundir suas idéias.

ALVIM (1986, p. 40), que realizou uma vasta pesquisa sobre a imigração italiana no Brasil e centrou seus estudos nos imigrantes que se radicaram no meio rural, corrobora esta postura quando se refere ao tipo de ação desenvolvido pelos italianos no interior paulista:

"Em termos assistenciais e polficos ela (a ação) se espelha nas inúmeras Sociedades de Mútuo Socorro (SMS) espalhadas por todo o estado e nas respostas aos apelos lançados pelos grupos anarquistas, para problemas referentes à comunidade italiana. Partindo de cidades com grande concentração de italianos, tais apelos comprovam que essa facção política penetrou no interior paulista." 
balho, a exploração do trabalho infantil, as condições insalubres das fábricas, que motivaram o operariado a se mobilizar em movimentos reivindicatórios e políticos.

A história oficial foi influenciada por essa teoria da planta exótica (FAUSTO, 1976), tanto que, segundo MAGNANI (1982), os estudos da legislação trabalhista se atêm ao perlodo após 1930 , como se as lutas anteriores não tivessem ocorrido.

Os primeiros estudos sobre o Movimento Operário no Brasil, partiram de autores ligados à política operária, fosse através dos sindicatos ou dos partidos políticos e datam da década de 50 e inicio dos anos 60 .

Embora tivessem o mérito de descortinar o véu, deram ao anarquismo uma importância secundária, de preparo para a fundação do Partido Comunista, visto como fruto do amadurecimento da consciência de classe.

Ainda segundo MAGNANI (1982), datam do início da década de 60 , as obras que retratam as memórias de militantes operários. Esses autores procuram contrapor suas interpretações àquelas comunistas e enxergam nas primeiras lutas trabalhistas a influência marcante do anarquismo. Evidenciam que, após 1922, o Movimento Operário se rendeu às influências do comunismo e do tra * balhismo oficial e perdeu o intuito inicial tornando-se mais reformista que revolucionário.

A autora situa nesta linha Edgar Leuenroth e Edgar Rodrigues. Acrescentariamos a estes autores EVERARDO DIAS (1977), que, embora adepto do comunismo, em suas memórias evidencia a marcante atuação anarquista na configuraçäo do Movimento Operărio do início do século.

Continuando sua análise historiográfica, MAGNANI (1982), afirma que as produções acadêmicas sobre o Movimento Operårio datam de meados da década de 60 , mas se prendem ao Sindicalismo e partem de 1930, enfocando este ano como um marco divisório, e analisando, principalmente, o papel do Estado.

Os trabalhos mais recentes buscam fazer uma reavaliação do perfodo conhecido como $1^{\text {a }}$ República e do Movimento Anarquista, procurando integrå-lo num todo maior, explicativo da conduta do operariado e analisando criticamente a estrutura sócio-econômico-polftica que ensejou o desenvolvimento das idéias anarquistas nos primeiros anos do século.

Magnani situa-se nesta última linha, assim como a maioria dos autores por nós consultados e que serão re. ferenciados no decorrer do trabalho. A autora chama ainda a atenção para o fato de que não se deve simplificar a análise da penetração do anarquismo no Brasil, julgando-o como um simples transplante de idéias que não tinham como florescer.

Concordamos plenamente com esta posição de Magnani, porque consideramos, sob a mesma ótica de MELLO (1988), que são as condições particulares de cada pals que imprimem as caracteristicas de um dado momento histórico. Recusamo-nos a considerar as influências externas de maneira determinística, privilegiando, assim, o espaço nacional como gerador de elementos impulsionadores do desenvolvimento.

Semina Ci. Soc./Hum., v. 15, n. 3, p. 260-269
A riqueza da bibliografia existente sobre o Anarquismo no Brasil, que centra sua análise nas cidades do Rio de Janeiro e São Paulo, pela importância que tiveram na implantação do capitalismo industrial, induz a um viés interpretativo que leva a minimizar as experiências anarquistas ocorridas em outras cidades brasileiras, caso de Curitiba, por exemplo, que foi palco, durante as primeiras décadas deste século, de movimentos trabalhistas influenciados pelo anarquismo.

Embora tenhamos elaborado um tese de mestrado que evoca a presença anarquista em Curitiba (VALENTE, 1992), neste trabalho pretendemos recuperar apenas os traços mais gerais da penetração do ideário anarquista no Brasil, procurando dividi-lo em fases que permitam uma compreensão mais clara das ações anarquistas mais significativas em cada momento histórico.

\section{2 - FASES DO PROCESSO HISTÓRICO ANARQUISTA NO BRASIL}

O Anarquismo se fez presente no Brasil muito antes da política de imigração massiva e do processo de industrialização, embora esses dois fenômenos tenham dado o suporte necessário para a ampliação da influênca desse ideário, principalmente entre o operariado.

Inúmeras experiências de criação de núcleos habitacionais fundamentados no anarquismo, e calcados numa economia agrária e artesanal foram colocados em prática, ainda durante o período imperial, como atesta RODRIGUES (1969, p, 30):

"Experiências em moldes cooperativos, comunidades igualitárias de vida em comum, apareciam constantemente no Brasil, e podemos afirmar que têm sempre algo que as identifique com as idéias de Robert Owen ou Fourier."

Entre as colônias fundadas sob a inspiração anarquista, o autor cita: Guararema, no Estado de São Paulo, fundada por Artur Campagnolli, em 1888; e Cecília, no Estado do Paraná, fundada por Giovanni Rossi, em 1890. Refere-se também à influência dos anarquistas no meio rural, organizando reuniōes e palestras, com a finalidade de difundir suas idéias.

ALVIM (1986, p. 40), que realizou uma vasta pesquisa sobre a imigração italiana no Brasil e centrou seus estudos nos imigrantes que se radicaram no meio rural, corrobora esta postura quando se refere ao tipo de ação desenvolvido pelos italianos no interior paulista:

"Em termos assistenciais e polticos ela (a ação) se espetha nas inúmeras Sociedades de Mútuo Socorro (SMS) espalhadas por todo o estado e nas iespostas aos apelos lançados pelos grupos anarquistas, para problemas referentes à comunidade italiana. Partindo de cidades com grande concentração de italianos, tais apelos comprovam que essa facção politica penetrou no interior paulisia." 
Para melhor compreensão da influência do ideário anarquista no Brasil, autorizamo-nos a estabelecer três fases. Fases estas que dependeram do inter-relacionamento de fatores internos e externos de índole, principalmente, político-econômica. São elas:

1ํ Fase - compreende o perfodo 1850-1888: proibição do tråfico negreiro até a abolição da escravatura.

$2^{a}$ Fase - abrange o período 1889-1906: proclamação da República - até o I Congresso Operário Brasileiro.

3- Fase - abarca o perlodo 1906-1922: data de fundação do Partido Comunista.

Na primeira fase (1850-1888), o Brasil, internamente, sofria o processo da paulatina extinção da escravatura. À medida que essa foi perdendo terreno, a imigração foi aumentando.

DIEGUEZ JUNIOR (1964, p. 25), argumenta que com a lei de 1850 , que estabelecia a proibição do tráfico de escravos, foi dado o primeiro golpe na instituição escravocrata. Diz ele: "Todo esse pertodo - de $1850 \mathrm{em}$ diante, e até alcançar o 13 de Maio - de luta contra o trabalho escravo (a.s) Ate 1850 a situação é esta: de luta, de constante luta contra a escravidāo, e também de luta "em favor da imigração."

Externamente, a Europa estava assolada de problemas: a população apresentava um rápido crescimento, havia a questão da pauperização da população rural, crises políticas e agrícolas, o regime de propriedades de terras - que alijava o camponês - $\mathrm{e}_{\imath}$ coroando tudo isso, uma ampla propaganda patrocinada pelos países que pretendiam o braço imigrante e que criava expectativas favoráveis de vida no novo mundo.

Esses fatores, associados, fizeram com que a face da sociedade brasileira principiasse a mudar o tecido $\$ 0$. cial foi se colorindo de novos matizes, outras visôes de mundo se incorporaram às jâ existentes.

Esses primeiros imigrantes que aqui chegaram, en. contraram trabalhadores nacionais que comecavam a se organizar em funçäo das suas péssimas condiçőes de vi. da, mas que não tinham uma noçăo muito clara das causas que motivavam sua miserabilidade.

Eram organizações, portanto, com objetivo mais assistencial que reivindicatório e consistiam num campo fértil para a propagação do Ideário Anarquista. Ideário esse cuja influência transparece no modo de organizaçăo daquelas sociedades de trabalhadores que foram, na sua maioria, de cunho mutualista.

Entrevemos nesse primeiro período, um anarquismo com ênfase na união dos homens para superarem dificuldades comuns, mais preocupado com as condições de vida do trabalhador, com sua conscientização, do que com a organização de movimentos sociais de maior amplitude. Mesmo porque as próprias características da sociedade brasileira, eminentemente rural e contando com escassos meios de comunicação, não possibilitava uma ação mais abrangente.

Semina Ci. Soc,/Hum., v. 15, n. 3, p. 260-269
A segunda fase (1889-1906) abrange um periodo no qual o Brasil passou por profundas transformações sócio-político-económicas: deu-se o fim da escravatura e do Império; a República foi proclamada; o país passou a investir maciçamente na imigração porque a lavoura precisava de braços e amplas áreas de terras necessitavam ser colonizadas.

A Europa fornecia imigrantes e o Brasil se apressava em recebê-los. Nem sempre da maneira mais adequada, como evidenciam os inúmeros relatos a respeito do tratamento que lhes era dado.

A história do começo do século é uma história conturbada, onde um novo regime - a República, que privilegiava os interesses da oligarquia cafeeira - come çou a se implantar e novos valores e crenças passaram a ser incorporados.

Foi uma época onde o trabalhador principiou a adquirir consciência política, as cidades iniciaram os processos de higienização e modernização e o Estado, ainda va* cilante, tendo enfrentado revoltas como a de Canudos e Contestado, precisou criar mecanismos que permitissem sua consolidação.

A constituição de 1891, que se auto intitulou democrática, por retirar de seu texto o voto censitário, alijou do processo eleitoral uma grande parcela da população, na medida em que restringiu o direito de voto aos homens alfabetizados e maiores de 21 anos, em um pais onde $80 \%$ da população era analfabeta (NAGLE, 1986; PAIVA. 1973).

Além disso, as fraudes eleitorais, o mando politico dos senhores rurais - coronéis -, a política do café com leite, com grupos políticos de São Paulo e Minas Gerais se alternando no poder, o voto a bico de pena e os currais eleitorais evidenciavam o comprometimento do Estado com a oligarquia cafeeira. Portanto. que democraciz era essa?

Com uma população nitidamene rural e com uma economia fortemente agrária seria făcul para o Estado manter o controle da situaça. não fossem os movimen. tos reivindicatótios de um operariado que se mostrava cada vez mais insatisfeito com sua condiçäo: baxos sala rios e uma jornada de trabatho que chegava, em média a 14 horas diarias durante 6 a 7 dias por semana. Situaçăo essa que perdurou atế 1932, quando Gexullo Vargas pro. mulgou lei determinando 8 horas de trabalho dierrio.

Nessa fase (1889-1906) surgiu a preocupação pu. jante, objetiva e metódica, com a divulgação do ideário anarquista, principalmente através de periódicos que tinham a possibilidade de atingir um grande número de receptores.

As condiçỏes estavam postas: industrialização nascente, trabalhadores insatisfeitos, intelectuais engajados na militância. 
Já em 1894, alguns remanescentes da Colônia Cecllia 1, que havia sido extinta, se dirigiram à Curitiba e nesta cidade editaram o jornal II Lavoratore, sob a responsabilidade de Gigi Damiani.

Tanto RODRIGUES (1969) quanto FERREIRA (1988) e DULLES (1977), entre outros, citam inúmeros periódicos editados pelos anarquistas já que estes julgavam constituírem os jornais um poderoso meio de educação política. FERREIRA (1988) afirma que:

"De um modo geral, todos esses jornais eram de orientação anarquista ou anarcossindicalista, visto que seus idealizadores eram, na maioria das vezes, componentes daquele contingente de imigrantes deportados ou refugiados por questões polfiticas..."

Julgamos que essas diferentes posturas: anarquismo e anarcossindicalismo refletiam aquela mesma situação existente na Europa após o Congresso de Haya (1872) que cindiu a I Internacional em duas vertentes: a anarquista e a marxista.

Depois dessa cisão, a vertente anarquista ou antiautoritåria que influenciou a França, Espanha, Itália, Bélgica e os demais palses latino-americanos, passou a se concentrar em duas posiçöes: aquela que encarava o sindicato como o meio mais adequado para a deflagração da greve geral e, posteriormente, da Revolução Social e se denominou anarcossindicalista - e, a que não privilegiou o sindicato como vetor das transformações sociais e que passou a ser conhecida como anarquista.

RODRIGUES (1988) possibilita-nos compreender com clareza as diferenças das duas posições anarquistas. Diz ele que o Movimento Anarquista tem o indivíduo como ponto de referência, cujos limites são aqueles estabelecidos pela sua liberdade e inteligência: é a revolução das consciências; enquanto que o anarcossindicalismo ô tanto uma doutrina quanto um método de luta. Seu núcleo central é o trabalhador que deverå gerir a sociedade a ser erigida após a derrocada do capitalismo. Para tanto. apóla-se nas organizações operărias: sindicatos uniỏes $_{i}$ federaçôes.

DULLES (1977) chega a sugerir que a imprensa proletária surgiu com o intuito de convencer os trabalha dores que, oprimidos pela baixa remuneração e por um período de trabalho exaustivo, não se apercebiam do seu estado de sujeição e miséria.

Entendemos que essa análise do autor é bastante reducionista, jå que transparece na sua fala a concepção de um trabalhador passivo, mero receptáculo de novas ideologias. Julgamos que se esse discurso anarquista se fez tão intenso é porque havia receptores interessados e atentos. Trabalhadores que já haviam se apercebido da sua precária condição de vida e tentado se organizar, mas que não tinham ainda tomado consciência de que a causa da miséria era estrutural. A imprensa anarquista, portanto, espelhava os anseios da classe trabalhadora naquele momento histórico.

Esses jornais tinham vida curta devido às dificuldades econômicas - já que sobreviviam da subvenção dos trabalhadores - e à repressão policial, mas exerceram grande influência, abordando os temas mais diversos e deixando evidente como o imaginário anarquista enfocava a educação formal, a mulher, a criança, a família, o casamento, o jogo, as diversões - carnaval, futebol -, a moral, além, é claro, dos assuntos pertinentes ao trabatho.

Mas a preocupação dos anarquistas ou libertários com a educação politica não se limitava aos periódicos: fundaram escolas - Escolas Modernas ou Racionalistas Centros de Estudos, Bibliotecas, Universidades Populares; promoveram reuniōes e panfletagens; desenvolveram uma intensa produção teatral e literária. Enfim, sua atividade educacional espraiou-se por todos os campos culturais, como atesta HARDMAN (1984, p. 85): "A mo" ral anarquista esteve sempre preocupada em mostrar uma fortaleza cultural que resistisse aos males da ordem dominante e fosse como um campo de treinamento para as comunidades do porvir."

Aralisando o discurso anarquista, chamou-nos a atenção a maneira diversa dele encarar os elementos relativos à educação política, entendida em sentido lato. $E$ permanente nesse discurso a tensão existente entre o conservador e o avançado. Quando enfocava os jogos e as diversões - baile, carnaval, futebol -, era extremamente reacicnário em relaçāo a essas atividades e as condenava inapelavelmente, por minarem o poder de resistência do operário e abalarem a sua dignidade, mas o mesmo não acontecia em relação à educação, ao casamento e à condição feminina, pois apresentava uma visão extremamente avançada para a época. Visão que até hoje ê contemporânea.

Os anarquistas percebiam corr. clareza a funçăo educacional como mantenedora da ideologia do Estado e, por isso, eram frontalmente contrários a um processo educacional formal mantido pelo poder pủblico. Apregoavam uma educação vinculada aos interesses do operariado e por ele gerida; uma educação que tornasse as pessoas conscientes e críticas e não meras reprodutoras dos papéis sociais que interessavam ao Estado. Encaravam a educação como fator de transformação, mas sem delegar à ela poderes miraculosos, sem desvinculá-la do todo que a circunda e ao qual está essencialmente vinculada.

Essa concepção educacional foi difundida e defendida, na prática, através da criação de Escolas, Centros de Estudos Sociais e Universidades Populares.

1. Comunidade anarquista, em moldes experimentais, fundada por anarquistas italianos no Paranł́, na região denominada Campos Gerais, que teve breve duraçäo: 1890-1894. Com sua extinção vários dos seus integrantes passaram a residir em Curitiba, onde deram infcio ao Movimento Operário.

Semina Ci. Soc./Hum., v. 15, n. 3, p. 260-269 
Os Centros de Estudos Sociais eram locais de educação informal onde se difundia o ideário anarquista. Quanto às Escolas, centravam suas atividades nas propostas pedagógicas de Robin - Educação Integral - e Ferrer - Ensino Racionalista.

GHIRALDELLI JUNIOR (1987, p. 113) explicita muito bem a proposta pedagógica de Robin: "A idêia central contida na proposta de Educaçāo Integral, (...) era a da máxima importância à atividade e ao trabalho, pois o trabalho era encarado como o fundamental princlpio educativo."

Mas, mais do que as idéias de Robin, foram as experiências de Ferrer, contemporâneo dos anarquistas brasileiros, que empolgaram o ideário pedagógico desenvolvido no Brasil, pelos anárquicos, e influenciaram a abertura de escolas nos moldes das que existiam na Espanha. Essas Escolas, denominadas Modernas, e que defendiam o Ensino Racionalista, propunham uma ação pedagógica voltada para os interesses dos explorados.

Contrariando os interesses das classes dominantes e enfrentando cerrada oposição de setores da Igreja e do Estado, tiveram enorme dificuldade para se manter e acabaram sendo fechadas na esteira de uma verdadeira caça aos anarquistas, muitos dos quais foram deportados sob acusaçäo de conspirarem contra o governo.

Um outro empreendimento educacional dos anar. quistas consistiu na criação de Universidades Popula* res.

GHIRALDELLI JUNIOR (1987) ressalta que elas foram de curta duração e parcos resultados e cita, como exemplo, a Universidade Popular fundada no Rio de Ja. neiro, que perdurou de março a outubro de 1904.

Aponta como possivel causa do fracasso da experiência, o desnivel entre mestres e alunos, dada a grande competência intelectual dos primeiras.

Os elementos derivados da pesquisa não nos possibilitam chegar a conclusões mais acuradas sobre as causas que motivaram o fracasso dessa iniciativa. No entanto, permitem-nos acrescentar um outro dado àquele fornecido por Ghiraldelli, qual seja o da criação da Universidade Popular de Piracicaba (REVISTA A ESCO. LA, 1910), cidade do interior de São Paulo, em 1910, demonstrando que a idéia não se extinguiu tão precoce. mente ${ }^{2}$.

Um ponto altamente polêmico, era a visão de casamento dos anarquistas, melhor diria, união consensual, jå que condenavam o casamento religioso e civil por considerá-lo uma maneira de obrigar as pessoas a permanecerem unidas. Defendiam que essa união deveria ser destituida de qualquer vinculo institucional e ser fundada tão somente no amor - dal a expressăo: "os anarquistas são partidários do amor livre"."

$\mathrm{Na}$ realidade eles foram muito mal interpretados pela sociedade da época: seus contemporâneos não conseguiram perceber a profunda coerência desta atitude com a ideologia libertária: como o anarquista desconsiderava a Igreja e o Estado, năo havia sentido em recorrer aos dois para legalizar uma união.

A conotação que teve esta postura, foi a conotação de libertinagem, de pessoas preocupadas em trocar de parceiros constantemente. No entanto, o que se percebe é que essas uniōes foram duradouras e, com o decorrer dos anos e o arrefecimento do anarquismo, assim como pela pressäo social, acabaram por ser legalizadas.

A este respeito é muito elucidativo o depoimento do Sr. WERTHER NERVO ${ }^{3}$ :

"Eles não casavam na Igreja, nem no civil. Eles só juntavam. Tanto é, eu me lembro, depois quando eu já era moço, eu lembro que muitos ite. lianos começaram a casar depois de velhos. Meu pai e minha mãe se casaram. Isso eu jå era moço".

Em relação à mulher, os anarquistas tinham uma postura diametralmente diversa da burguesia. Enquanto esta reservava para a mulher os papéis de esposa e mãe, a serem exercidos com recato e dignidade, os anárquicos defendiam a necessidade da educação politica da mulher porque só assim ela poderia ser companheira do homem e não criar obstáculos para sua participação na militância. Homem e mulher eram iguais e deveriam ser tratados como tal em todos os niveis: educação, política, trabalho.

Durante essa fase, que consideramos aquela na qual o ideário anarquista principiou a penetrar no Movimento Operário Brasileiro, devido ao incipiente processo de industrialização, foram muitos os anarquistas de ou. tros paises que aqui desenvolveram militância.

CARVALHO (apud RODRIGUES, 1988, po 129) aponta como a nata dos militantes anarquistas no Brasil. em 1904, os seguintes nomes: "Benjamim Motta, Neno Vasco, Angelo Bandoni, Evaristo de Morais, Diulio Bernadoni, Fábio Luz, Manoel Moscoso, Juan Bautista Perez, $T_{\text {. Boni, }} A_{0}$ Cerchiai, Sorelina Gordani, Maria d'Oliveira, etc."

Acrescemos a estes nomes apontados por CARVAL.HO, os de Gigi Damiani e Orestes Ristori, italianos, que àquela época exerceram grande atividade intelectual ${ }_{s}$ tanto editando jornais quanto colaborando com periódicos ou ministrando palestras. E o de Edgar Leuenroth.

2. A revista publicou o Programa da Universidade Popular condensado em sete artigos, que evidenciam a preocupação em unir a formação intelectual com a preparaçäo para o trabalho, o desenvolvimento físico e os sentimentos de solidariedade. Consta do programa a preocupação com o estabelecimento de uma "escola prática doméstica" a fim de preparar as moças para serem donas de casa. Este tencionava ser colocado em prática através de conferências, aulas, concertos, bỉbliotecas, teatro ao ar livre, festas e fogos populares. A Universidade Popular pretendia ser mantida com a contribuição financeira dos membros fundadores, contribuintes, remidos, beneméritos e honorários e a matéria publicada especifica os valores a serem pagos por cada uma das categorias.

3. Sr. Werther, sobrinho de Alessandro Cerchiai, jornalista italiano que escreveu em periódicos anarquistas no início do século. Entrevistas gravadas em 19/09/89 e 25/10/91, na cidade de Londrina.

Semina Ci. Soc.JHum., v. 15, n. 3, p. 260-269 
brasileiro, pela marcante atividade jornalística. Seus arquivos foram doados à UNICAMP e são hoje imprescindiveis para as pesquisas que tenham como objeto 0 Anarquismo. Leuenroth foi, inclusive, um dos responsáveis pela edição do periódico anarquista que mais perdurou: "A Lanterna".

Percebemos nestes nomes arrolados dois aspectos que chamam a atenção: primeiro, a presença de intelectuais brasileiros, como Făbio Luz e Evaristo de Morais, embora este, como explica Rodrigues, nunca tivesse se declarado anarquista; segundo, a presença de intelectuais provindos de outros paises referendando a importância que tiveram os imigrantes, principalmente os intelectuais, na divulgação do ideário anarquista, o que é corroborado por FERREIRA (1976, p. 92):

\section{"O processo de politização que se iniciou com a chegada e participação do operário imigrante foi o ponto mais importante da história do trabaiha- dor brasileiro. Entretanto, não se pode mostrar este processo sem tocar no papel desempenha- do pelos intelectuais, sem o qual não teria havido a grande movimentação e difusão das doutrinas sociais no meio operário ${ }^{\text {" }}$}

Entendemos esse intelectual militante, engajado, cujo discurso provém da classe e se dirige para a classe como um intelectual orgânico, de acordo com a visăo de GRAMSCI (1978). Um intelectual que critica a estrutura capitalista, mas que não pretende estabelecer normas de conduta para a burguesia, como faz o intelectual comprometido com a burguesia, em relação ao operariado.

O discurso do intelectual orgânico se caracteriza es * sencialmente por sua identidade ideológica, vivência e convivência com a classe dominada e isto transparece nas atividades desenvolvidas pelos intelectuais anarquistas

Apesar das circunstâncias adversas, os intelectuais estrangeiros permaneceram em nosso pais um tempo relativamente longo e lançaram sementes com grande poder germinativo, pois, já em 1903, aconteceram as primeiras greves com carảter reivindicatório - destacando-se entre elas a greve geral no Rio de Janeiro, pela jornada de 8 horas e por melhores salários $-{ }_{2}$ e teve início a organização sindical (DIAS, 1977).

A terceira fase de influência do ideário anarquista principiou com a realização do I Congresso Operário Bra sileiro, em abril de 1906, que optou pelo anarcossindica. lismo, em detrimento do socialismo reformista e do trabalhismo, correntes que influenciavam o Movimento Operário (FAUSTO, 1976), e perdurou até cerca de 1922, quando militares dissidentes do anarcossindicalismo fundaram o Partido Comunista (GHIRALDELL) JUNIOR, 1987).

No entanto, já em 1912, este predominio do anarcossindicalismo começou a ser abalado (KOVAL, 1982). com a realização de um Congresso Operário patrocinado por Hermes da Fonseca, com a finalidade de formar um partido político.

DIAS (1977) afirma que participaram desse Congresso 187 delegados e foram debatidas e aprovadas 14 teses. Entre elas destacamos: a) horário de oito horas de trabalho; b) descanso semanal; c) limitação do trabalho noturno das mulheres e dos menores de 14 anos; d) salários máximos e mínimos; e el instrução e educação pública do proletariado.

O Congresso encerrou no dia 15 de Novembro com a fundação da Confederação Brasileira do Trabalho como Partido Político.

A partir desse momento, entendemos que a cooptaçăo das lideranças operárias, pelo Estado, ficou claramente configurada. Uma cooptação que, em 1930, adquiriu contornos bem mais nitidos e imprimiu, dali em diante, a feição dos sindicatos.

Entre 1907 e 1930, a perseguição aos anarquistas foi implacável. O governo não dava trégua: prendia, torturava, deportava para o Acre e expulsava do país os elementos mais ativos ${ }^{4}$.

Arthur Bernardes, presidente do pais entre 1922 e 1926. desencadeou violenta repressão aos anarquistas. Em seu governo, aconteceu uma insurreição militar (tenentismo, 1924) que serviu de pretexto para a instalação do Estado de Sítio e para a perseguição aos anarquistas com o explicito propósito de "fechar definitivamente os sindicatos liyres, eliminar os militantes mais ativos. expulsando-os am massa do território brasileiro confinando-se em ilthas-presidio campos de concentraçäo. (TODO PODER situados no extremo norte do país - limite com a Guiana Francesa - em local denominado Colonia Agrícola de Clevelândia, região insalubre, onde os desterrados morriam de febre e inanição.

Alguns conseguiram fugir e narrar a experiência. Entre eles: Pedro Alves Carneiro, pintor de paredes; An ronio Alves Costa, pedreiro; Domingos Passos carpinbeiro; Pedro Carneiro; Domingos Braz; Manoel Ferreira Gomes, pedreiro; Tomaz Derlitz Borche; Biophilo Panm ciasta; Pedro O. Mota; Antônio Salgado; Antônio Roux; José Batista de Araůjo, pedreiro. Outros ficaram sepulta. dos no local: Pedro Augusto Mota, ex-redator de A Plebe; José Maria Fernandes Varela, gráfico; Nino Martins, gráfico; Nicolau Parada, garçon; José Alves do Nasci mento, garçon.

Mas, apesar de existência de uma legislação que possibilitava ao Estado tomar as atitudes mais arbitrárias, esse foi um perfodo de intensa atividade por parte dos anarquistas: fundaram escolas, centro de estudos, jornais e revistas; organizaram greves e boicotes; promoveram manifestaçōes, debates, reuniões e palestras, criaram inưmeros sindicatos, federações e associaçōes operárias a realizaram congressos em várias cidades, inclusive o $2^{\circ}$ Congresso Operårio, em 1913, e o $3^{\circ}$ Congresso Operário, em 1920.

4. Segundo o Anuário Estatístico do Brasil (1939/40) ano V apud MARAM, SHELDON LESLIE (1979, p. 43), entre os anos 1907-1921 foram expulsos 556 imigrantes sendo 113 espanhóis, 121 italianos, 181 portugueses e 141 de outras nacionalidades.

Semina Ci. Soc.JHum., v. 15, n. 3, p. 260-269 
De 1906 a 1921 (DIAS, 1977), não houve um ano sequer no qual as greves deixassem de ocorrer, e é muito sintomático que toda essa atividade febril tenha se manifestado com mais intensidade após o I Congresso Operário Brasileiro, realizado no Centro Galego do Rio de Janeiro, entre os dias 15 e 20 do mês de Abril de 1906. Participaram desse Congresso cerca de 40 organizações, sendo a grande maioria do Rio de Janeiro e de São Pau10.

No Congresso foram discutidas várias teses, relativas à orientação, organização, ação operária e questões acessórias ou complementares. As que foram aprovadas deixaram evidente a opção do Movimento Operário pela orientação anarcossindicalista. Ficou decidido, também, o sistema federativo das organizações operárias, dando ampla autonomia ao individuo no sindicato, ao sindicato na federação, e à federação na confederação.

Condenou-se a beneficência, o mutualismo e o cooperativismo, descredenciando, portanto, as formas de organização que haviam imperado até o momento.

Quanto às ações a serem desencadeadas, foram recomendadas greves parciais ou gerais, boicotes, atos de sabotagem e manifestações públicas.

Recomendou-se, também, a luta pela jornada de 8 horas diárias de trabalho. A luta por melhores salários não constou das recomendações, pois se julgava que o aumento salarial seria decorrente da diminuição da jornada de trabalho.

Finalmente, recomendou-se que o $1^{\circ}$ de Maio fosse comemorado de maneira mais condigna, de acordo com os ideais da luta operária e não com jogos ou piqueniques.

Por resolução do Congresso, fundou-se o jornal "A Voz do Trabalhador", cuja publicação teve início a 19 de Fevereiro de 1908.

Organizada a Confederação Operária Brasileira, em 1908 , desde logo aconteceram as adesões: cerca de 50 associações representando as mais diversas categorias de

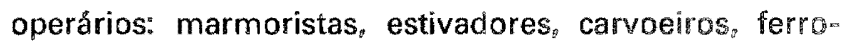
viários, chapeleiros, gráficos ${ }_{q}$ bombeiros $_{q}$ entre outros se ligaram à Confederação.

Nessa época - 1907 - segundo o recenseamento do Brasil reaiizado em 1920 lapud KOVAL, 1982, $p_{0} 126$ ) a concentração do proletariado industrial do Brasil tinha a seguinte configuração: havia no total 151.841 operårios, assim distribuldos: Estado de São Paulo, 22.355 (14,7\%); Distrito Federal e Estado do Rio de Janeiro, 47.004 (31\%); Rio Grande do Sul, 15.426 (10,2\%) e Minas Gerais, 9.307 $(6,1 \%)$. Esses Estados compreendiam $62 \%$ do total de operários brasileiros, sendo que São Paulo e Rio de Janeiro contavam com $45,7 \%$. Dal a importância que adqui- riram na História do Movimento Operário Brasileiro, como palco das grandes lutas que se travaram em prol da melhoria de vida do operariado. $O$ que de maneira alguma minimiza as ações que foram desencadeadas nos outros Estado e que colocaram em evidência no Brasil a Questão Social ${ }^{5}$. Uma Questão que acompanhou toda a evolução econômico-social brasileira desde os seus primórdios, ainda que não fosse reconhecido seu cunho poIftico, e que foi aumentando de intensidade conforme aumentavam o número de operários e as tensões sociais.

CEROUEIRA FILHO (1982) analisando a Questão Social, em nível do discurso político hegemônico, se reporta ao não reconhecimento dela, como existente no Brasil. Esta falta de reconhecimento levava as elites a não considerá-la como uma questão a ser resolvida pela via política. Portanto, na 1 a República, a Questão Social foi, essencialmente, um caso de polícia.

Os conflitos entre capital e trabalho que tornaram tenso o ambiente das duas primeiras décadas desse século, foram resolvidos, ou melhor, abafados através de atitudes repressivas ou cooptativas, por parte do Estado.

Por parte do operariado, conformismo e rebeldia se alternavam, numa atitude dúbia de resignação e revolta perante as condiçôes de trabalho a que se via submetido, como bem explicita DECCA (1990).

O levantamento histórico da ação anarquista no Brasil, deixa evidenciadas as reações do governo a cada embate havido entre o operariado e o patronato.

Cumpre enfatizar que o Estado, fiel ao princípio não intervencionista - influência liberal na Constituição - deixava que patrōes e empregados realizassem a livre negociação. Mas, quando chamado a intervir, posicionava-se francamente ao lado do capital.

$\mathrm{Na}$ arena de lutas da 1- República, o operariado fa. zia greves para demonstrar seu descontentamento e o Estado contra atacava elaborando leis baixando decretos ou procurando cooptar os lifderes sindicalistas.

Como resposta aos movimentos grevistas ocorridos na fase anterior (1900-1906), em Janeiro de 1907 o Go. verno Federal sancionou duas resoluções decretadas pelo Congresso Nacional.

Decreto 1637 - exigia que os sindicatos depositas sem seus estatutos em cartórios acompanhados de uma lista com o nome da diretoria, da qual só podiam fazer parte brasileiros natos ou cidadãos naturalizados e residentes no País há 5 anos.

Decreto 1641 - Lei Adolfo Gordo 6 - permitia expulsar do pais os estrangeiros que comprometessem a segurança nacional ou a tranqüilidade pública. Não atingia os estrangeiros casados com brasileiras, viúvos com fi-

5. A exemplo de CERQUEIRA FILHO, (1982, p. 21) entendemos a Questão Social como "Conjunto de problemas polfticos, sociais e econômicos (...) vinculados ao conflito entre capital e trabalho."

6. A respeito dessa lei, afirmou Dias $\left(1977\right.$, p. 222) ${ }^{\prime \prime}$... uma lei que era um misto de tudo quanto de reacionário havia sido votado nos Parlamentos dos palses mais reacionários da Europa, para ser aplicada ao nosso Pals. Chegava a premiar a delação (...). Era uma lei para escravos, abertamente favorável ao patrảo, cuja palavra bastava para levar um operário à cadeia como delinquente e atirar com ele nos seringais do Acre ou nos sertöes do Nordeste, ainda infestados de bugues agressivos."

Semina Ci. Soc./Hum., v. 15, n. 3, p. 260-269 
Ihos brasileiros e estrangeiros com 2 anos de residêcia no pals.

Essas exceções eram raramente respeitadas e acabaram sendo revogadas, por Hermes da Fonseca, em 1913.

A lei Adolfo Gordo gerou intensos protestos na imprensa libertária e não impediu que as greves continuassem ocorrendo.

No entanto, embora a classe dominante continuasse a se recusar em reconhecer a questão social como inexistente $^{7}$ e a inscrevê-la no seu pensamento, a não sèr esporadicamente, a verdade é que ela existia e os reciamos se faziam insistentes. Reclamos cuja abrangência extrapolava a classe operária e permeava outras instâncias: a nascente classe média, composta por profissionais liberais, assalariados e funcionários civis e militares, era também atingida pela carestia (inflação), pelos baixos salários, pelo desemprego, pelas péssimas condições de trabalho, pela falta de uma legislação que a amparasse.

O Governo se viu impelido, portanto, a criar leis que atendessem aos reclamos generalizados. Leis visando a mulher e a criança apareceram a partir de 1917 (LUZ, 1982; POSSAS, 1989) . O Código Sanitário de 1919 trazia medidas pra protegê-las - proibia o trabalho para menores de 14 anos e trabalho noturno para as mulheres.

O Regulamento Nacional da Saúde Pública (RAGO. 1985), de 1923, facilitava a licença maternidade por 30 dias e fazia a proposta de lugares adequados para amamentação, nos locais de trabalho.

FAORO (1977, p. 609) se refere ao cuidado das elites em admitir as reivindicações sociais e dar-lhes um rumo e cita RUI BARBOSA: "(Os imigrantes) trouxeram ao Brasilo criaram no Brasĭ questäo social. Ela urge conesco por medidas, que com serisdade

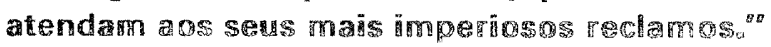

Notamos nesse pronunciamento de Rü Barbose um tom acusatorio contra os imigrantes, quando, na ver. dade eles näo trouxeram s. sim colocaram em avidench

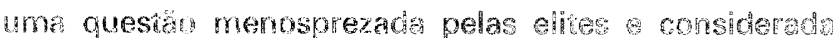

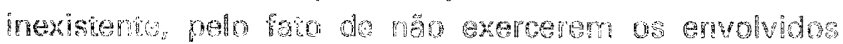

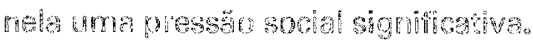

Enquanco a quesân sncial dissa respeiro aos hotos

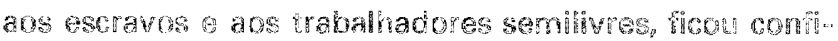

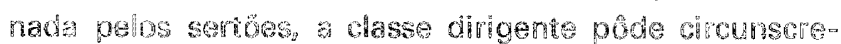

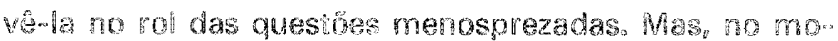
mento em que provocou manifestaçes, greves, boicctes, produziu uma imprensa ${ }$ sacudiu o marasmo de ume 50. ciedade embalada nos sonhos de uma rantasia, a questä social forçou sua inscriçăo no rol dos elementos que precisavam ser considerados com mais cuidado pelo Estado. Tanto que, em 1930, Getủito Vargas começarå a desen. volver um governo de cunho populista, cooptará as lide ranças sindicais, presentearâ os trabalhadores com um
Ministério e uma legislação e pretenderá para si todos os louros, obscurecendo as lutas que se travaram anteriormente.

Por seu lado, a nascente Burguesia Industrial também buscava criar mecanismos que controlassem os conflitos entre capital e trabalho. Criou as Associações Patronais, com o objetivo explícito de melhorar as condiçőes de vida dos trabalhadores, mas que implicitamente pretendiam controlar e disciplinar seus hábitos; e as Fichas Cadastrais, que mantinham toda a atividade do trabalhador sob controle e que serviam para os industriais trocarem informações entre si.

Em busca de angariar simpatias, os industriais chegavam a capitalizar as conquistas operårias, fazendo com que estas assumissem a forma de benefícios.

Além disso, como evidencia brilhantemente RAGO (1985), o empresariado buscou assumir o controle da vida operária estabelecendo uma estratégia disciplinar que não permitia um espaço sequer de liberdade.

Todos os aspectos da vida dos operários passaram a ser programados, segundo o modelo burguês de adequabilidade: na fábrica, no lazer, no lar, na familia, em suas relações com a mulher e os filhos, o operário devia agir segundo o imaginário burguês.

Para colocar em prática o seu propósito, a burguesia industrial contou com a colaboração de médicos, pedagogos e engenheiros, que comungavam do mesmo ponto de vista.

$\mathrm{Na}$ medida em que foi se adequando ao novo modelo de vida, o operário foi perdendo sua identidade cultural.

A imprensa libertåria estampou muitos artigos que denunciavam a atitude do patronato e questionavam a

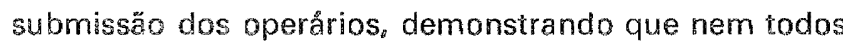
eram cegos ao que estava ocorrendo.

No entanto a pressão econômica era forte o sufi. ciente para fazer com que, por medo de perder o empre. $\mathrm{go}_{0}$ as imposicöss rossem sendo paulatinamente aceirab

o poerariado sofrendo uma dipla segregacáo - por? um lado preconceibn quamo an trabaho manual c, por outo preconceito contre o imigrante - e näp rendo th. reitos polícos, entreviu no anarcossindicailsmo a nas formas de acuaço propostas por els - organizaça do sindicatos, boicotes, greves, uma forma de resistencia. organização e luta fola dos modelos insticuiros pelo fos. tados.

Durante a fase na qual a influência do anarcossind: calismo foi predominante, sucederam vários periodos de atuação do operariado: alguns nos quais esta atuação esteve nitidamente em descenso ou estabilizada e outros nos quais a atividade operária esteve em franca ascensầo.

FAUSTO (1976) aponta como um perlodo de dificuldades para a organização e reação dos operários

7. Jorge Street, empresário, em conferência proferida no Instituto de Engenharia de Säo Paulo, em 29/09/34 (IN MORAES FILHO, org.. 1980, p. 15), assim se pronunciou ao reconhecer este fato: "Negar a existência de uma questäo social no Brasil foi um erro. É certo que entre nós o problema năo se apresentava com a acuidade dos outros povos. No entanto, ela existia. Se entre nós o trabalhador nunca teve (...) uma vida que se pudesse, nem de longe, chamar de tragédia (...) havia entre nós no entanto, incontestavelmente, abusos e injustiças contra crianças, mulheres e, mesmo, operários homens $(. . .)^{\prime \prime}$.

Semina Ci. Soc.JHum., v. 15, n. 3, p. 260-269 
aquele compreendido entre 1913 e 1917. Os motivos foram vários, entre eles: baixo preço para os produtos de exportação e manutenção do nivel de importações, que provocou o primeiro "déficit" na balança de pagamentos brasileira. Além da $1^{\text {a }}$ Guerra Mundial, a paralisação da entrada de capitais estrangeiros e a remessa de capital para pagamento da divida externa. Estes fatores causaram recessão, desemprego, redução de salários e perda das pequenas conquistas trabalhistas.

Citando levantamento efetuado por AZIZ SIMÃO, FAUSTO (1976, p. 157) afirma que, neste perlodo, ocorreram "apenas: uma greve de fábrica, em São Paulo, em 1914; duas greves setoriais (ramo) em 1915; uma em uma fábrica e uma setorial em 1916."

Bem diferente foi o próximo perfodo, compreendido entre julho de 1917 a 1920, que teve início com uma greve geral em São Paulo irradiada para vários pontos do pals, inclusive Curitiba e outras cidades do Paraná (DIÁRIO DA TARDE, 1917). Foi o periodo onde ocorreu o maior número de greves da História do Brasil: 109 na cidade de São Paulo; 32 no interior do Estado de São Paulo; 63 no Rio de Janeiro, apenas para exemplificar.

Foi, também, o período no qual surgiu nos centros urbanos do país um movimento social de base operária, que se refletiu em inúmeras atividades: greves, manifestaçōes de massa, crescente sindicalização, ampliação da imprensa operária e surgimento da expectativa de uma mudança vinculada à Revolução Social, ou à esperança, ao menos, de uma melhoria do nivel de vida.

Apesar da Revoluçăo Russa ter ocorrido em 1917. este não parece ter sido um fator determinante para a ebulição deste período $e_{\text {, }}$ sim, o nível insuportável de vida a que se via submetido o operariado.

Imediatamente, começou a impiedosa repressão por parte do Estado, que se estenderia até esmagar completamente o anarquismo nas fileiras operárias.

Após 1920, a influência anarquista no Movimento Operário entrou em declínio devido à forte ação policial que impedia toda e qualquer atividade, à expulsão dos líderes e à ascensão do prestígio dos comunistas e do trabalhismo oficial. A fundação do Partido Comunista, ern
1922. pode ser considerada como o marco definitivo no descenso da influência anarquista no Movimento Operário que passará a ter, a partir daí, a orientaçäo do comunismo e do trabalhismo oficial até 1930 , quando Vargas inaugurará, definitivamente, a fase do sindicalismo pelego.

\section{3 - CONCLUSÃO}

\author{
"E um fato novo se viu \\ Que a todos admirava: \\ O que o operário dizia \\ Outro operário escutava. \\ $E$ foi assim que o operário \\ Do edificio em construção \\ Que sempre dizia sim \\ Começou a dizer não \\ E aprendeu a notar coisas \\ A que não dava atenção..."
}

\section{(Vinicius de Moraes)}

O Anarquismo emprestou ao Brasil da 1ㄹ República e, principalmente, ao Movimento Operário, um sopro de vitalidade, coragem entusiasmo e paixão.

Não há dúvida de que adquiriu em nosso pais a configuração que era possivivel na sociedade daquela épo. ca: teve as limitações impostas pelo analfabetismo, pela despolitização e pela desorganização dos trabalhadores. assim como, pela intransigência e opressäo das oligarquias. No entanto, seus militantes não se acovardaram perante a imensa tarefa que se apresentava e desenvol= veram um sem número de estratégias visando a educa. ção, a politização e a organização dos trabalhadores。

Os anarquistas foram vencidos não só pela ação intransigente do Estado, mas também pelas dissenções internas. No entanto, suas açōes não foram em vão: suas vozes, suas caminhadas, suas posturas, deixaram marcas indeléveis que a História se encarrega de resgatar, evi. denciando a importância do ideário anarquista na forma ção da consciência de classe do trabalhador brasileiro.

VALENTE, S.M.P. The anarchical movement in Brazil. Semina: Ci. Soc./Hum., Londrina, v. 15, n. 3 , p. 260-269, Sept. 1994.

ABSTRACT: The anarchical historic process in Brazil has, according to our point of view, three significant phases, due to political and economical events which made up the setting for the workers reivindicatory activities influenced by anarchical idealism:

KEY-WORDS: Anarchism, Workers, Political education, Brazil, The First Republic

\begin{tabular}{|c|c|}
\hline \multicolumn{2}{|c|}{ REFERÊNCIAS BIBLIOGRAFICAS } \\
\hline $\begin{array}{l}\text { ALVIM, Z.M.F. Brava gentel: os italianos em São Paulo } \\
\text { 1870-1920. 2. ed. São Paulo: Brasiliense, } 1986 .\end{array}$ & $\begin{array}{l}\text { COSTA, C.T. O que é anarquismo? 13. ed. São Paulo: } \\
\text { Brasiliense, } 1988 .\end{array}$ \\
\hline $\begin{array}{l}\text { CERQUEIRA FILHO, G. A questão social no Brasil: critica do } \\
\text { discurso polltico. Rio de Janeiro: Civilização Brasileira, } \\
1982 .\end{array}$ & $\begin{array}{l}\text { DECCA, M.A.G. de Cotidiano de trabalhadores na República: São } \\
\text { Paulo 1889/1940. São Paulo: Brasiliense, } 1990 .\end{array}$ \\
\hline
\end{tabular}


DIÁRIO DA TARDE, Curitiba, 19, 20, 21, 22, 23 de jul. 1917. p. 1

DIAS, E. Historia das lutas sociais no Brasit. 2. ed. São Paulo: Alfa Ômega, 1977.

DIÉG UES JUNIOR, M. Imigração, urbanização $e$ industrialização. Rio de Janeiro: Centro Brasileiro de Pesquisas Educacionais, 1964.

DULLES, J.W.F. Anarquistas e comunistas no Brasil (1900-1935). 2. ed. Rio de Janeiro: Nova Fronteira, 1977.

FAORO, R. Os donos do poder. Rio de Janeiro: Globo, 1977.

FAUSTO, B. Trabalho urbano e conflito social. São Paulo: Difel, 1976.

FERREIRA, M.N. Imprensa e sociedade: o trabalhador gráfico. São Paulo, 1976. Tese. Universidade de São Paulo.

FERREIRA, M.N. Imprensa operåria no Brasil. São Paulo: Ática, 1988.

GHIRALDELLI JUNIOR, P. Educaçăo e movimento operårio. São Paulo: Cortez, 1987.

GRAMSCl, A. Os intelectuais e a organização da cultura. 2. ed. Rio de Janeiro: Civilização Brasileira, 1978.

HARDMAN, F.F. Nem pátria, nem patrão: vida operária e cultura anarquista no Brasil. 2. ed. São Paulo: Brasiliense, 1984.

KO VAL, B. História do proletariado brasileiro. São Paulo: Alfa Ômega, 1982.

LUZ, M. Medicina e ordem polltica brasileira: polftica e instituiçóes de saúde (1850-1930). Rio de Janeiro: Global 1982.

MAGNANI, S.L. O movimento anarquista em Săo Paulo (1906-1917) São Paulo: Brasiliense $e_{p} 1982_{0}$
MARAM, S.L. Anarquistas, imigrantes e o movimento operário brasileiro (1890-1920). Rio de Janeiro: Paz e Terra, 1979.

MELLO, J.M.C. de O capitalismo tardio. 7. ed. São Paulo: Brasiliense, 1988

MORAES FILHO (org.), E. de Ideias sociais de jorge street. Brasflia: Senado Federal, Rio de Janeiro: Fundação Casa de Rui Barbosa/MEC. 1980.

NA GLE, J. Educaçăo e sociedade na Primeira República. São Paulo: EPU/MEC, 1986.

PAIVA, V. Educação popular e educação de adultos. São Paulo: Loyola, 1973.

POSSAS, C. Saude e trabalho: a crise da Previdência Social. 2. ed. São Paulo: HUCITEC, 1989.

RAGO, L.M. Do cabaré ao lar: a utopia da cidade disciplinar. Rio de Janeiro: Guanabara Koogan, 1986.

REVISTA A ESCOLA, Curitiba, v. 5, n. 7/12, jul./dez. 1910.

RODRIGUES, E. Socialismo e sindicalismo no Brasil. Rio de Janeiro: Laemmert, 1969.

RODRIGUES, E. Os libertários: idéias e experiências anárquicas. Petrópolis: Vozes, 1988.

TODO poder ao povo, não ao partido. U topia, São Paulo, p. 10-14, 1990.

VALENTE, S.M.P. A presença rebelde na cidade sorriso: contribuição ao estudo do anarquismo em Curitiba 1890-1920. Campinas, 1992. Tese. Universidade Estadual de Campinas.

Recebido para publicaçåo em 22/03/1994 